\title{
Impact on the video game industry during the COVID-19 pandemic
}

\author{
Ortiz Luz ${ }^{1}$ \\ ORCID:https://orcid.org/0000-0001- \\ 5194-0113 \\ leortize@uce.edu.ec \\ Universidad Central del Ecuador \\ Quito-Ecuador \\ Chimbo Christian ${ }^{3}$ \\ ORCID:https://orcid.org/0000-0001- \\ 7602-1711 \\ christian.chimbo@udla.edu.ec \\ Universidad de las Américas \\ Quito-Ecuador
}

\author{
Tillerias Héctor ${ }^{2}$ \\ ORCID:https://orcid.org/0000-0001- \\ $6305-2711$ \\ htillerias@gmail.com \\ Universidad de las Fuerzas Armadas \\ Quito-Ecuador \\ Toaza Verónica ${ }^{4}$ \\ ORCID:https://orcid.org/0000-0002- \\ $7830-2813$ \\ veronicatoaza@gmail.com \\ Instituto Superior Tecnológico Luis A \\ Martínez \\ Ambato-Ecuador
}

Recibido (07/08/20), Aceptado (18/08/20)

\begin{abstract}
This work presents trends and comparisons that show a change in the consumption and production of video games in times of confinement due to the health emergency. The video game industry has modified its philosophy and adapted its products to the new requirements and trends of consumers who see in this activity a way to appease the psychological and social impact due to quarantine and isolation. There is evidence of a $65 \%$ increase in the use of online video games, which has broken a world record. Products that have new aspects and considerations never before proposed by this great industry have been developed and offered, such as thematic games related to the COVID-19 pandemic.
\end{abstract}

Keywords: Video game, pandemic, online games, confinement.

\section{Impacto en la Industria de los videojuegos durante la pandemia por COVID-19}

\begin{abstract}
Resumen: Este trabajo presenta tendencias y comparaciones que evidencian un cambio en el consumo y producción de los videojuegos en tiempos de confinamiento debido a la emergencia sanitaria. La industria de los videojuegos ha modificado su filosofía y ha adaptado sus productos a los nuevos requerimientos y tendencias de los consumidores, quienes ven en esta actividad, una forma de apaciguar el impacto psicológico y social debido a la cuarentena y aislamiento. Se evidencia un incremento del $65 \%$ en el uso de videojuegos en línea, la cual ha batido record a nivel mundial. Se han desarrollado y ofertado productos que poseen nuevos aspectos y consideraciones nunca antes propuestos por esta gran industria como los juegos temáticos relacionados con la pandemia por COVID-19.
\end{abstract}

Palabras Clave: Videojuego, pandemia, juegos en línea, confinamiento. 


\section{I.INTRODUCTION}

Changes in social, economic and psychological aspects such as isolation, the global market crash and behavioral variations in people, have been imposed unexpectedly during the quarantine period caused by the Covid-19 pandemic worldwide [1]. These changes have been internalized by multiple industries and sectors that have expanded their market niches to improve productivity and economic growth. The video game industry, when linked to the world of entertainment and influenced by these changes, has increased its demand in the last two years and has become a domestic activity within a normal day at home, presenting a record in sales and a predominant positioning in the world market [2].

Even before the pandemic, the growth in demand for video games was evident, therefore, its philosophy of continuous improvement has managed to capture the attention of its consumers through the use of cellular devices, implementing new technologies and through the incorporation of new techniques like non-player characters that allow the implementation of dynamic, credible and strategically unpredictable behaviors, which make the player want to get involved in the game's plot, capturing their attention considerably [3].

The current situation has motivated the video game industry to focus its attention on promoting online games which, from the user's point of view, offers an escape from reality to have fun safely, foster relationships with others people and share experiences, sometimes fostering empathy and creating pro-social themes [4].

The educational system, also affected by social distancing, has seen in video games the opportunity to keep its students safe and at the same time keep them entertained. In recent years, teachers have integrated video games and virtual education as a way of fostering global empathy in children and young people, in other words, interest and curiosity to learn more about other countries and feel identified with their cultures [5] [6], as well as strengthening their skills and technical abilities [7]. Video games as a learning tool highlight the following typical characteristics of a 21 st century video gamer: Being the strategist by fulfilling missions, being the creator by making his own game, being the communicator by building relationships and communities, being the hero by overcoming a great adventure, and be the creator of worlds and situations [8] [10]. However, there are video games that provide violent and socially resentful content, which is why it is important that parents accompany them in choosing and controlling the type of video game their allowed to play, especially amongst younglings $[11][12]$.

The possibility of using online multiplayer video games has become a tool for users of all ages and even in organizations in which these activities are of notable interest within the course of their working hours [13].

The largest number of video game sales worldwide during the quarantine, consist of Grand Theft Auto V, Red Dead Redemption 2, FIFA 20 and in the rpg category, Tomb Rider has emerged. During this time, the increase in users has been substantial in the market due to the quarantine and the notable influence that these video games have had even when they were already well positioned comercially [14] [16].

The quarantine marked a before and after in the video game industry since it has encouraged users from all over the world to learn and enjoy a good video game and, above all, mark a challenge for their designers in order to adapt them to the new user requirements and demands [17] [18].

The advantages of using video games has also been an important factor in the development of new products in the environment of this pandemic. It should therefore be taken into account that play lowers anxiety levels [19], contributes to intelligence, ensuring good judgment in decisión making and the importance of playing in safe spaces and in family ties.

Taking into account that the excessive use of video games could also alter the behavior of children and young people, other studies affirm that the moderate use of video games can be a powerful pedagogical tool to enhance learning not only in traditional content, but also in the formation of social and digital skills, which are key to function in modern society and include: concentration and the ability to multitask[20]. They can also positively affect reaction time, processing speed, and reduce stress levels.

The video game industry has offered new thematic products in its different genres or categories in order to help and inform children, young people and adults of the risks of exposing themselves without protection to the outside environment. For example, in Spain the company Virtual Recall [21] has developed a game called Coronavirus Attack for mobile devices and computers in which players must destroy COVID-19 by means of a ship, positioning it in the adventure and action genre. Another game developed by the company Omnium Lab, called Covid Game, is designed for mobile devices and tablets and encourages children to stay at home and experience multiple situations teaching them to have good hygiene and prevention habits such as washing their hands. 
Covid Game is placed in the adventure genre as well [22]. Other games in the educational games category have also been released during the pandemic, such as Immune Attack and Foldit, which help children understand the configuration of molecules and biological processes through 3D puzzles. Within the sports category, games such as esports have been highlighted in favor of avoiding contagion risks [23]. And furthermore, video games are at the forefront of the online battle arena multiplayer genre too with famous titles, such as Leguage of Legends [24], whose generated profits contribute to campaigns to combat COVID-19.

\section{II.DEVELOPING}

Impact of the Video Game Industry due to the COVID-19 pandemic.

\section{A.Video game consumer trends}

The COVID-19 pandemic produced a total change in the habit and ways of living of people, as well as affecting the way they consume their products and the performance of habits at home. The use of video games has taken an important position within the 20 most important activities that people prefer to carry out during quarantine [25], as presented in Figure 1.

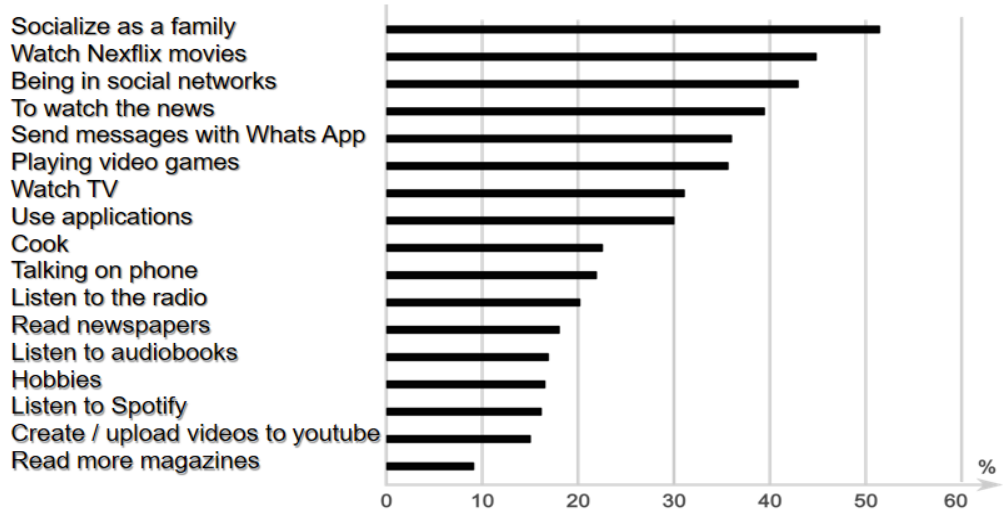

Fig. 1 - Activity usage graph during quarantine [25]

The growing demand in the consumption of video games during quarantine has revealed economic changes to the benefit of this industry showing an increase in the sales within the countries with the highest video game consumers (China 250\% in video game sales and Australia 285\% in sales of consoles), as well as consoles during the quarantine [26], in short, breaking records sales and impacting the world market on a large scale (figure 2).

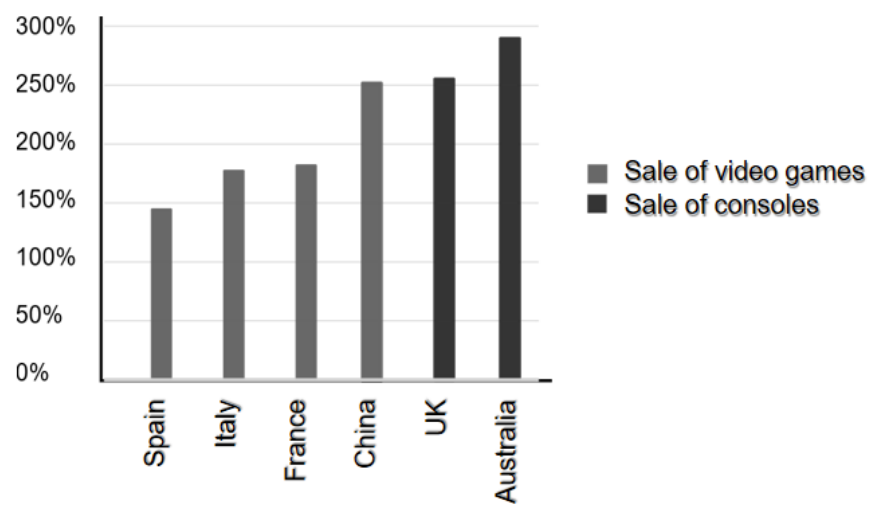

Fig. 2. Graph of video game and console sales in some countries [26] 
The rapid growth of the video game industry also entails a degree of uncertainty in investors who, despite benefiting at present, cannot fully anticipate the new changes that will occur when returning to normality after the pandemic.

Young people between the ages of 13 and 24 have doubled their time spent in video games, impacting the big brands. Both the video game industry and other sectors have seen the need to train their employees in the area of social networking as a strategy to maintain investment in the face of new users called hyperconnected users[27].

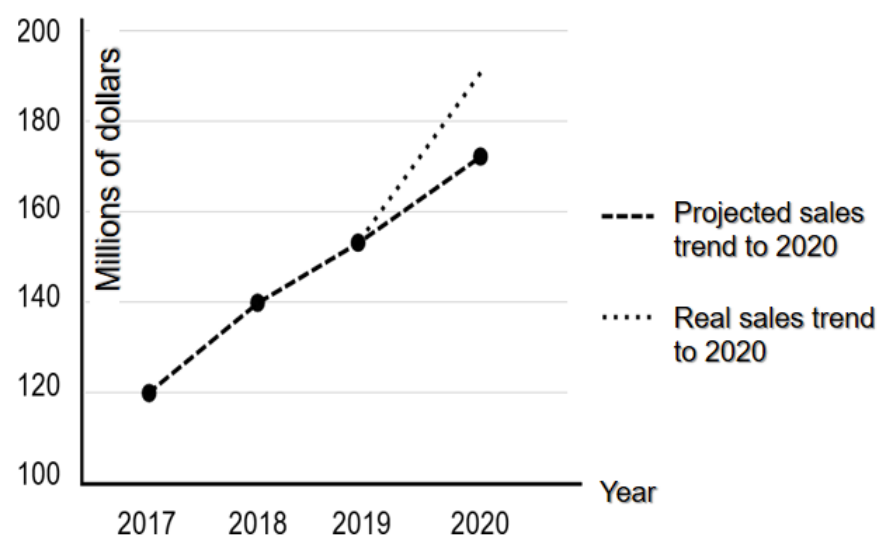

Fig. 3. Real and programmed trend of video game sales in 2020 in Billions of dollars

Figure 3 consists of a graph that shows the increase in real sales, comparing them with the projected sales for the last 3 years up to the first months of 2020 [26] [28], exceeding projected expectations and forecasts by $30 \%$ more in gains from 168 to 188.8 billion dollars in video games.

Regarding the games that have been downloaded the most during the pandemic, there are Hunter Assassin, with almost 100 million downloads between Google Play and the App Store, followed by Brain Out (slightly less than 90 million), Johnny Trigger and Woodturning (above out of 75 million) and PUBG Mobile slightly below 75 million downloads [29].

In figure 4, the countries mentioned in this section are highlighted in terms of video game consumption throughout the first two quarters of 2020, as a result of the quarantine and taking into account the number of downloads, evidencing except for China, growth compared to the months after February. It is worth mentioning that China was one of the countries that faster overcame the confinement and returned to its normal activity, which would explain the downloads decrease, for the same months [30].

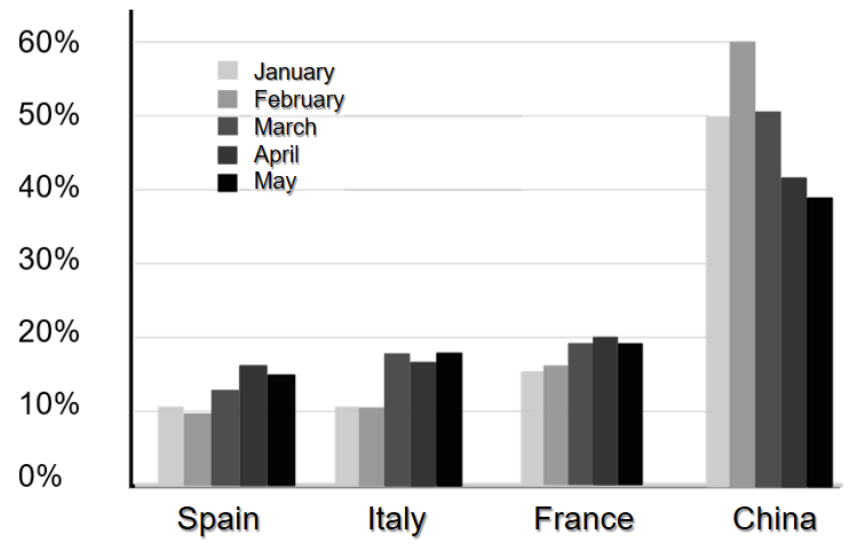

Fig. 4. Video game consumption trends in 2020 in Millions of downloads [30] 


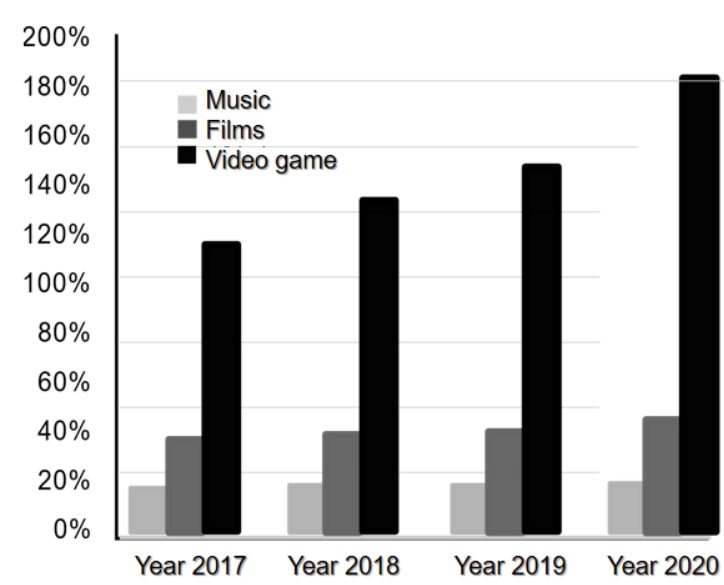

Fig. 5. Comparative graph between user preferences for entertainment in billions of dollars [32]

The notable increase in video games can be justified because, since 2010, video games were not only constituted in the field of entertainment, but also incurred in the educational and cultural field, while films and music still have more representation in the field of entertainment. These considerations enshrine the growth of the profits generated evidenced from 2017 to 2020, even without considering the effect of the COVID-19 pandemic.

At present, the production and design aspects of video games have become crucial, since new products are required as a consequence of the current situation, forcing a change in habits and thus promoting the consumption of online video games.

\section{B.Changes in the video game industry in times of pandemic.}

Based on a review of the titles promoted for the year 2020, it can be considered that the video game industry, with respect to the supply of its products, has not been significantly affected [33]. However, the only drawbacks have been face to face events on this subject.

The production regarding the most widely accepted consoles in the world, incorporates developments with improvements in technology and immersive capacity of the player towards the video game. For the use of the PlayStation 5 (PS5) platform, Sony Interactive Entertainment has presented the video game alternatives compatible with the new console, among these titles are new games in the usual categories in Adventure, strategy, sports, action, simulation and role. As a new contribution due to the influence of the situation, the game Plague INC, Envolve, was promoted for PlayStation, which has characteristics of a realistic simulation and strategy game in which the player must survive the extinction of humanity caused by a lethal pandemic [34]. This game was available on the App Store for eight years, but it has been withdrawn from the gaming scenarios for being considered an inappropriate game in times of pandemic, since the game includes material related to viruses in humanity that could be confused with alteration of information on COVID-19 [35].

The video game industry, together with the World Health Organization (WHO), have proposed in a campaign, the use of a video game called PlayApartToghter, whose purpose is to socialize messages and preventive actions promoted by this institution in order to avoid the spread of the Covid-19 [36] [37].

\section{C.Trends in the workplace in the video game industry}

The impact of the video game industry during the quarantine has created trends in its users, especially high school youth when choosing a university degree, and it is precisely that video game design has become an official profession today [38], and is catapulted into the most demanded and best paid careers, due to the consumption generated in this last semester. This trend has created certain advantages, such as the convenience of studying online at home, time flexibility, and affordable. Today this profession is being promoted throughout the world through universities [39].

Unlike the rest of the productive sectors where the impact of the pandemic has generated unemployment, in the video game industry, the number of hires has grown and benefited professionals in this area [40]. At present, these professionals are part of a stable and safe profession, not only due to times of pandemic, but also due to the 
growth of this industry since before the crisis. Figure 6, extracted from [40], presents the demand for experts compared to the professions in the field of multimedia production, where it is evident that video game designers are well positioned with respect to the other disciplines.

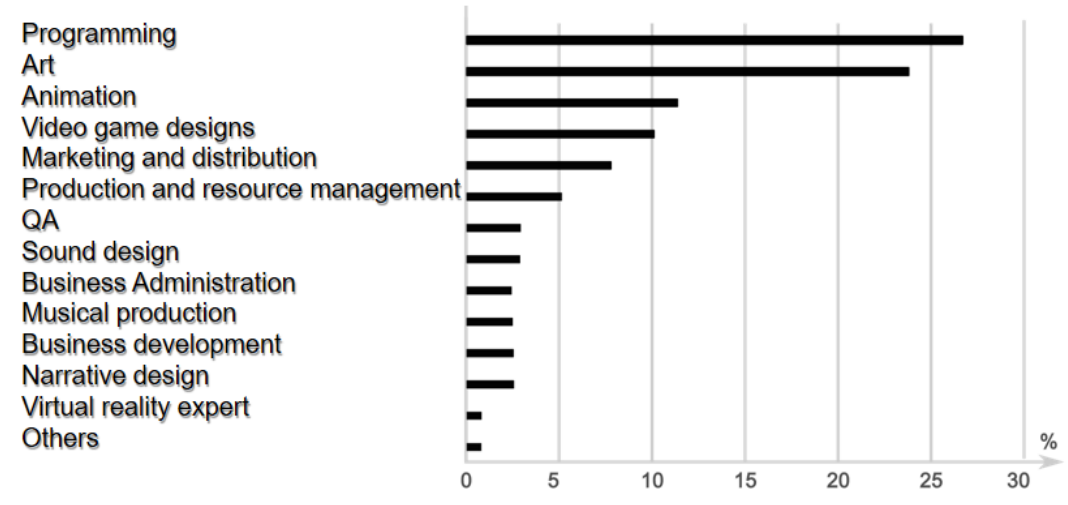

Fig. 6. Job offers in the field of multimedia production by type of profile in 2020 [40]

In addition to this, there are $49 \%$ of workers in the video game industry who are not over 30 years old and only $3 \%$ are over 45 . Of this total of employees, $71 \%$ have completed higher education (undergraduate, graduate) and $23 \%$ have completed intermediate studies (diploma, higher vocational training). However, 53\% of the companies claim not to have hired a properly competent staff, the reason being the lack of experience within the technique that evolves rapidly [40].

\section{III.METHODOLOGY}

For this work, the bibliographic research was considered, taking into account three fundamental aspects that are the trends of the video game consumer, the changes that the video game industry has experienced and the labor aspect that this industry offers.

Regarding consumer trends, an exhaustive search was carried out for preferences, countries with the highest consumption of these products.

To expose the changes that the video game industry has presented, new products have been sought and analyzed, the relevant aspects that benefit the sector, opportunities and decisions regarding the adaptation that has been made to better satisfy the customer.

Finally, statistics have been presented on the job opportunity that video game designers currently have, in addition to the influence that video games have on decisions about related professional careers and their advantages.

\section{IV.RESULTS}

16 scientific articles from the years 2019 and 2020 were analyzed, compiled from magazines related to studies of the video game industry, and multidisciplinary sources, in addition, statistics from reports of 20 web pages on the subject under study were considered, in which took into account the collection of those that were strictly relevant to COVID-19.

$35.5 \%$ [25] (figure 1) of users who prefer video games were evidenced, as part of the time spent working and doing household activities. This figure includes the family, especially the children and young people of the house, evidenced by surveys by the Research \& Insights company, which is a social and market research agency.

The massive consumption of video games has positioned China with $250 \%$ more sales of video games, this figure has been maintained in the last 3 years, due to its large population and the continuous improvement of technologies [26] (figure 2).

Countries such as Spain experienced a great demand of video game designers and developers who can satisfy the massive consumption that especially has had an exponential growth in the first half of 2020 due to the pan- 
demic. A demand for programmers is evidenced in 27\% (figure 7) [40].

The massive sale and download of video games during the quarantine is explained by the confinement of children and young people who have changed their daily activities and certain habits due to the closure of schools and colleges, in addition to outdoor and shared activities, such as sports activities, group games and among others.

An abrupt rise in 2019 was observed in the analysis with an increase in global sales in the video game industry by 20.8 billion dollars, which represents $30 \%$ of profits compared to COVID- 19 .

The impact of the video game industry has caused countries such as China, France, Italy and Spain to predominate video game downloads on mobile devices, increasing by $30 \%$ less in China, which shows growth of more than 60 Millions of downloads in the month of February.

\section{V.CONCLUSIONS}

The global impact that the COVID-19 pandemic has determined in the world of video games has been clearly evidenced not only in sales figures, but also in changes in learning strategies, marketing and habits in children, youth and adults within their homes that, of course, will unleash social, economic and psychological consequences.

It must be remembered that video games were initially developed in a solitary way, but this evolved and network games became a great attraction for consumers, but in this time of pandemic there was a much more relevant growth, being the development of meetings and collaboration between users are being one of the fields in evolution.

In the labor field, the demand for professionals increases due to this health crisis, as well as the lack of experience and academic training on the part of professionals in the field of programming, as a competition in this new era of video games and new styles of lifetime.

\section{REFERENCES}

[1]M. Olff, Screening for consequences of trauma-an update on the global collaboration on traumatic stress. European Journal of Psychotraumatology, 2020

[2]Z. Li, China's Digital Content Publishing Industry: The 2019 Annual Report on Investment Insights and Market Trends. Publishing Research Quarterly, 2020

[3]R. Agis, An event-driven behavior trees extension to facilitate non-player multi-agent coordination in video games, Expert Systems with Applications, 2020

[4]O. Wulansari, Video games and their correlation to empathy: How to teach and experience empathic emotion. Advances in Intelligent Systems and Computing, 2020

[5]C. Bachen, Simulating real lives: Promoting Global Empathy and Interest in Learning Through Simulation Games. Sage Journal, 2012

[6]S. Fowler, Intercultural simulation games: A review (of the united states and beyond). Sage Journals, 2010 [7]G. Chursin, Learning game development with Unity3D engine and Arduino microcontroller. Journal of Physics: Conference Series, 2019

[8]K. Hewett, The Acquisition of 21st-Century Skills Through Video Games: Minecraft Design Process Models and Their Web of Class Roles. Sage Journal, 2020

[9]R. Bayeck, Exploring video games and learning in South Africa: An integrative review. Educational Technology Research and Development, 2020

[10]K. Hewett, The 21 st-Century Classroom Gamer. Games and Culture, 2021.

[11]M. Coeckelbergh, Violent computer games, empathy, and cosmopolitanism. Ethics and Information Technology, 2007.

[12]S. de Smale, The Case of This War of Mine: A Production Studies Perspective on Moral Game Design. Games and Culture, 2019.

[13]L. Kapustina, Training employees in the digital economy with the use of video games. Advances in Intelligent Systems and Computing, 2020

[14]C. Zhan, A model for collective behaviour propagation: a case study of video game industry. Neural Computing and Applications, 2020. 
[15]B. Mei, A Novel Algorithm for Estimating Purchase Incentive of the Public Based on Mobile Cloud Computing. IEEE, 2019

[16]C. Zhan, Application of big data to cities in the United States. IEEE xplore, 2019

[17]G. Chanchí, Usability criteria for the design and construction of videogames. Repositorio Institucional: Universidad de Medellín, 2020.

[18]P. Garmen, Multiple intelligences and video games: Assessment and intervention with TOI software. Comunicar, 2019.

[19]Drafting. (2020). In moderation, video games have positive psychological effects during the coronavirus pandemic quarantine. Argentina: Infobae. Retrieved from: https://www.infobae.com/gaming/2020/05/07/ con-moderacion-los-videojuegos-tienen-efectos-psicologicos-positivos-durante-la-cuarentena-por-la-pandemia-de -coronavirus /

[20]Drafting. (2020). Videogames, a powerful pedagogical tool. ConsumptionTic. Recovered from: https:// www.consumotic.mx/videojuegos/videojuegos-poderosa-herramienta-pedagogica/

[21]Drafting. (2020). The Virtual Recall company designs a free video game to 'end' the pandemic. Spain: Europapress. Retrieved from: https://www.europapress.es/madrid/noticia-empresa-virtual-recall-disena-videojuego-gratuito-acabar-pandemia-20200325130148.html

[22]A. Arcos, Video games to learn how Covid-19 works. Colombia: Teaching., 2020, Recovered from: https:// www.magisnet.com/2020/04/videojuegos-para-conocer-como-funciona-el-covid-19/

[23]O. Well, Gamers' Video games that fight the coronavirus, discover exoplanets or deny Einstein. Spain: The Country, 2020, Recovered from: https://retina.elpais.com/retina/2020/04/21/innovacion/1587488219_287063. html

[24]A. Martín, The Virtual Recall company designs a free video game to 'end' the pandemic. Hypertextual, 2020 Recovered from: https://hipertextual.com/2020/06/league-of-legends-skins-covid-19

[25]Antevenio. Downloadable study: Zoom video games and the gamer world, how has the coronavirus impacted this market? Spain: Antevenio, 2020, Retrieved from: https://wwwantevenio.com/blog/2020/04/estudio-descargable-zoom-videojuegos-y-mundo-gamer-como-ha-impactado-el-coronavirus-en-este-mercado/

[26]V. Linares, The video game industry breaks records but fears post-lockdown. Rfi, 2020, Retrieved from: http://www.rfi.fr/es/economia/2020042 1-la-industria-de-los-videojuegos-bate-r\%C3\%A9cords-pero-teme-el-post-confinamiento

[27]Drafting. (2020). How the coronavirus has revolutionized consumption in Spain and how to take advantage of it in your marketing strategy. Spain: Antevenio. Recovered from: https://www.antevenio.com/blog/2020/03/ como-el-coronavirus-ha-revolucionado-el-consumo-en-espana/

[28]P. Rohner, Videogames, a silent industry, Spain: The Republic, 2020, Recovered from: https://www.larepublica.co/analisis/pascal-rohner-5 15246/videojuegos-una-industria-silenciosa-2749242

[29]O. Fernández, Downloading of video calling, education and news apps is skyrocketing in 2020. Spain: 20 minutes, 2020, Retrieved from: https://www.20minutos.es/noticia/4235561/0/la-descarga-de-apps-de-videollamadas-educacion-y-noticias-se-dispara-en-2020/

[30]M. Panier, Mobile Games: Evolution and Trends in 2020. Pickaso, 2020, Recovered from: https://pickaso. com/2020/juegos-moviles-evolucion-tendencia

[31]D. Jesús, Mobile Games: Evolution and Trends in 2020. Gameindustria, 2020, Recovered from: http://gamedustria.com/comparativa-de-ventas-ps4-xbox-one-switch-totales-y-mensuales-abril-2020/

[32]Drafting, If there is an industry that is not a game, it is Video Games in digital, 2018 Recovered from: https://en.digital/blog/videojuegos-industria-mobile-crecimiento

[33]A. Ramos, Video games achieve record sales in the US during the COVID-19 pandemic. United States: cnet, 2020, Retrieved from: https://www.cnet.com/es/noticias/videojuegos-logran-ventas-record-en-ee-uu-durante-la-pandemia-de-covid-19/

[34]Drafting. (2016). Plague Inc: Evolved. United States: playstation store. Recovered from: https://store.playstation.com/es-ec/product/UP1971-CUSA05119_00-1603060705021808

[35]Drafting. The Plague pandemic video game, victim of the coronavirus. (2020). Spain: digital economy. Retrieved from: https://www.economiadigital.es/tecnologia-y-tendades/el-videojuego-de-pandemias-plague-victima-del-coronavirus_20038827_102.html

[36]Drafting. (2020). The video game industry launched \#PlayApart Together, an initiative against the coronavi- 
rus. Argentina: Infobae. Retrieved from: https://www.infobae.com/gaming/2020/03/30/la-industria-de-los-videojuegos-lanzo-playaparttogheter-una-iniciativa-contra-el-coronavirus/

[37]Drafting. (2020). Global Gaming Industry Encourages Players to Follow Health and Safety Guidelines for COVID-19; Provide information and social connection. Businesswire. Retrieved from: https://www.businesswire.com/news/home/20200410005047/en/Games-Industry-Unites-Promote-World-Health-Organization

[38]O. Source, The best paid and most demanded professions of 2020. Spain: Iebschool, 2019, Retrieved from: https://www.iebschool.com/blog/profesiones-solicidas-bien-pagadas-recruto-seleccion/

[39]P. Ugochi, 15 best online game development schools in the world. World scholarship foum, 2020, Recovered from: https://worldscholarshipforum.com/es/best-online-game-development-schools/ [40] [40] Drafting, The video game industry in Spain: all the data for 2019. Spain: Antevenio, 2020, Retrieved from: https://www. antevenio.com/blog/2020/o3/la-industria-del-videojuego-en-espana-2019/

\section{CURRICULUM SUMMARY}

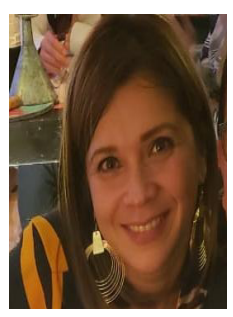

Luz Ortiz, She is the Coordinator of the Psychology

Career, develops her research in the area

of business innovation and human resources.

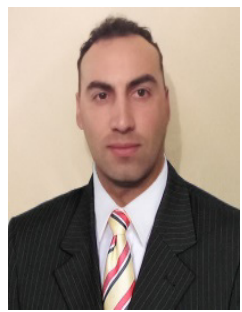

Héctor Tillerias, Master in Planning and Strategic Direction, graduate from the University of Armed Forces, Quito-Ecuador, degree in Military Sciences from the war Academy in Santiago-Chile, expert in supervision, management and training of human resources, with experiences in risk prevention and health promotion and quality of life in the workplace.

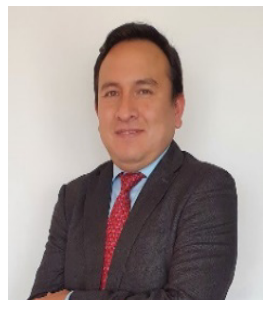

Christian Chimbo, He is Coordinator of the Industrial Engineering Career at the University of the Americas, Quito-Ecuador. He develops his research in the area of technological innovation applied to education.

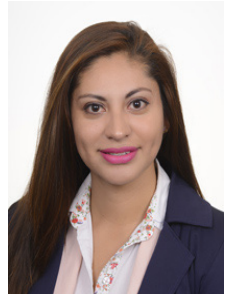

Veronica Toaza, Systems engineer from Catholic University to Ecuador, professor in a public Institute Luis A Martinez, Academic Director in a Regional College Food Engineers, experience in a webs systems, and teaching. 